DOI:

Este artigo está licenciado sob uma licença Creative Commons Atribuição 4.0 Internacional, que permite uso irrestrito, distribuição e reprodução em qualquer

\title{
BODILY INDIVIDUATION, BODILY RELATIONALITY - SCHELER'S PHENOMENOLOGY OF THE BODY AND INFANT RESEARCH
}

\author{
Individuação corporal, relacionabilidade corporal - a fenomenologia do corpo em Scheler e a \\ pesquisa infantil
}

Maria Chiara Bruttomesso*

\begin{abstract}
This article analyses two interrelated aspects of the phenomenological body - the fact of allowing a basic individuation and its being socially oriented from the beginning. To do that, I first present Scheler's theories on the lived body, focusing on the notions of Leibschema and of a primary individuation. I then assess Scheler's theory of the "undifferentiated flux" to show that it is only a prima facie impasse, and that an implicit body schema is present from birth; this seems to apply to the infant studies that find in newbors a "level 1" of detachment from the environment and an embodied selfawareness (Rochat, Fogel). However, the body schema shows an intrinsic relational aspect too. In the third part, I propose to apply Scheler's theory of the direct perception of expressivity to the psychological theories of an innate intersubjectivity (Trevarthen) and a core intersubjectivity (Stern). Moreover, the development of pre-linguistic infants seems to be possible thanks to lived-body and expressive interactions, that show co-regulation (Fogel) and affective attunement (Stern) in interaction.
\end{abstract}

Keywords: Lived body, Max Scheler, Infant research, Expressivity, Body schema.
Resumo: Este artigo analisa dois aspectos interrelacionados do corpo fenomenológico - o fato de permitir a individuação básica e o seu ser socialmente orientado desde o início. Para fazêlo, eu primeiro apresento as teorias de Scheler sobre o corpo vivenciado, focando nas noções de Leibschema e de uma individuação primária. Eu então abordo a teoria de Scheler sobre o "fluxo indiferenciado" para mostrar que é apenas um impasse prima facie, e que um esquema corpóreo implícito está presente desde o nascimento; isto parece se aplicar para os estudos da infância que encontram em recémnascidos um "nível 1" de desapego do entorno e uma autoconsciência corporalizada (Rochat, Fogel). Contudo, o esquema corpóreo demonstra um aspecto intrínseco relacional também. $\mathrm{Na}$ terceira parte, eu proponho aplicar a teoria de Scheler sobre a percepção direta da expressividade às teorias psicológicas de uma intersubjetividade inata (Trevarthen) e uma intersubjetividade nuclear (Stern). Ademais, o desenvolvimento de infantes pré-linguísticos parece ser possível graças ao corpo vivenciado e interações expressivas, as quais demonstram coregulação (Foger) e afinamento afetivo (Stern) na interação.

Palavras-chave: Corpo vivo, Max Scheler, Pesquisa infantil, Expressividade, Esquema corporal.

* PhD candidate, University of Verona, Italy. Scholarship of the University of Verona. mariachiara.bruttomesso@univr.it, mariachiara.bruttomesso@gmail.com

\begin{tabular}{|c|c|c|c|c|c|}
\hline intuitio & $\begin{array}{c}\text { ISSN } \\
1983-4012\end{array}$ & Porto Alegre & Vol.10- No.2 & $\begin{array}{c}\text { Dezembro } \\
2017\end{array}$ & p. 52-65 \\
\hline
\end{tabular}




\section{Introduction}

In his Formalismusbuch, written between 1913 and 1916, Scheler deals with the problem of corporeality through a peculiar example that indicates the first steps of the so-called Leibschema. I call this case "the example of the newborn". When a child observes her feet for the first time, she is tempted to hit them, as if they did not pertain to her bodily dimension but were rather an external object. Scheler claims here that she needs to learn the optic image (das optische Bild) of her body, and to distinguish it from the optic image of the bed sheets in which she is. ${ }^{1}$ So, where does the corporeal individuation emerge from? Does a newborn learn to differentiate her own corporeal sphere from the environment? And how could she ever do that, if she did not already have a structure (or schema) that allows her to feel this difference?

This example involves tangled phenomenological problems, first of all the definition of the longdebated notion of body schema, and secondly whether there is a distinction between this and the body image, which partially overlaps the optic image that Scheler assumes. Owning to the length and complexity of the debate on the body schema, a careful analysis of the problem cannot be addressed in this paper. On the whole, I agree with the differentiation between body schema and body image provided by Shaun Gallagher, who describes the body schema as a dynamic set of tacit bodily functions and performances. In other words, this results in close-to-automatic movements, which leaves one's attention free to focus on other tasks or objects. However, I do not share his characterization of it as "preconscious", since it concerns the pre-reflective, but still phenomenological layer of tacit governance of posture and movement. ${ }^{2}$ Differently, according to Gallagher the body image is «a complex set of intentional states and dispositions - perceptions, beliefs, and attitudes - in which the intentional object is one's own body», ${ }^{3}$ which includes a perceptual, a conceptual and an affective dimensions. The perceptual aspect, in Scheler's example, corresponds to the optic image that the child learns to individuate as her own.

The phenomenological implications at stake deeply concern the question of the primacy of selfindividuation over a relational constitution of the human being. More specifically, is this body schema primarily and intrinsically relational, or is there a previous individual dimension that allows for a sense of self-other discrimination, from which babies can learn their own image? And last, are newborns and

\footnotetext{
${ }^{1}$ GW II, p. 402. I refer in this paper to Scheler's complete works: SCHELER, M., Gesammelte Werke, Bonn: Bouvier-Verlag.

${ }^{2}$ GALLAGHER, S., How the Body Shapes the Mind, Oxford: Clarendon Press, 2005, p. 26. As Zahavi remarks, Gallagher either uses a too narrow concept of consciousness, or includes subpersonal, neural processes in the prereflective experience of the active performance of the body schema. Cf. ZAHAVI, D., Self-awareness and Alterity, Evanston: Northwestern University Press, 1999, pp. 94-99 and footnote 24.

${ }^{3}$ GALlAGHER, S., How the Body Shapes the Mind, Oxford: Clarendon Press, 2005, p. 25.
}

\begin{tabular}{|c|c|l|l|c|c|}
\hline intuitio & $\begin{array}{c}\text { ISSN } \\
1983-4012\end{array}$ & Porto Alegre & Vol.10- No.2 & $\begin{array}{c}\text { Dezembro } \\
2017\end{array}$ & p. 52-65 \\
\hline
\end{tabular}


infants capable of understanding the expressivity of others, if this capacity is rooted in the perception of lived bodies?

In this article, I mean not only to discuss Scheler's theories from a theoretical point of view, but also to compare them with the empirical evidence coming from infant research. Scheler's insights for the debate on the body schema and for the interrelational dimension in early infancy have been, as far as I know, almost ignored. ${ }^{4}$ However, there seem to be some meeting points between recent studies on infants and Scheler's theories on the lived body and the perception of expressivity. Newborns are able to imitate some basic gestures from the first days of their lives: this leads to the hypothesis of a primary body schema from birth (if not before), that would explain how they can perform the same gesture without knowing their bodily image. Moreover, not only a sense of their own body is shown to exist by those experiments, but also a sense of self-other discrimination, and much before self-recognition in the mirror. In this sense, one could further argue that the appeal to a primary intersubjectivity, and the phenomena of attunement and co-regulation move towards Scheler's theory, in case the basic level of empathy was conceived in terms of "perception" (Fremdwahrnehmung) and primacy of the expressive phenomena. I will first discuss the concepts of lived body and body schema in Scheler's research, and then investigate how "relational" this concept is to be interpreted, in order to discuss any evidence of an early capacity of empathy in infancy.

\section{Leib and Leibschema in Scheler}

Undoubtedly, the re-evaluation of a lived sphere of the body is one of the great merits of phenomenology. Scheler's most significant contributions to the subject of corporeality start between the end of his first period and the beginning of the second one. ${ }^{5}$ At the beginning of the phenomenological movement, namely with Die Idole der Selbsterkenntnis (1912), ${ }^{6}$ he discusses for the first time a distinction between Leib and Körper and starts stressing the originary givenness of the lived dimension in perception, a claim that he will maintain in all his written production. In Die Idole, Scheler sets the definitions of

\footnotetext{
${ }^{4}$ The best-known phenomenologist in this field is certainly Merleau-Ponty, whose work I will not assess, in order to focus on the main purpose of this paper. However, it would be interesting to investigate further Scheler's influence on the French phenomenologist's studies on infancy, as he himself quotes Wesen und Formen der Sympathie when investigating the sensitivity of the infant to expressivity, in MERLEAU-PONTY, M., Les Relations avec Autrui chez l'Enfant, Paris: Centre de Documentation Universitaire, 1951.

${ }^{5}$ Here I agree with Guido Cusinato, who chooses to distinguish three periods of Scheler's production according to his most important publications, namely: the first period (by 1912), the intermediate one (1913-1921, which includes the Formalismus and Vom Ewigen im Menschen) and the last one (1922-1928, which contains works like Wesen und Formen der Sympathie and Die Stellung des Menschen im Kosmos). Cf. CUSINATO, G., Katharsis: La morte dell'ego e il divino come aperture al mondo nella prospettiva di Max Scheler, Napoli: Edizioni Scientifiche Italiane, 1999, p. 36.

${ }^{6} \mathrm{GW}$ III.
}

\begin{tabular}{|c|c|l|l|c|c|}
\hline intuitio & $\begin{array}{c}\text { ISSN } \\
1983-4012\end{array}$ & Porto Alegre & Vol.10- $\mathrm{N}^{\circ} .2$ & $\begin{array}{c}\text { Dezembro } \\
2017\end{array}$ & p. 52-65 \\
\hline
\end{tabular}


external and internal perception, and states that the ownership and sameness of one's own body are immediate facts of both kinds of perception, without any doubt about self-attribution. ${ }^{7}$ Another aspect that is worth noticing in this text is the reference to a pre-noetic dimension of the lived body in action. In fact, Scheler examines the conditions that allow a fluid action, i.e.:

normal volition aims for the realization of the desired content directly, e.g. to leave the room. Any volition of the means necessary for this purpose, like "to step up to the door", "to press the handle", the execution of the movements necessary to the aim, and so on, is subordinated to that finalistic content and occurs through quasi-automatic impulses, insofar as no specific hindrance comes up ${ }^{8}$.

What is the connection between the concept of Leib that he maintains and the description of a prereflective purpose? It is remarkable that here Scheler reveals the theorization of a proto-concept of body schema. As stated in the introduction, the body schema is to be conceived as a dynamical structure that is implicit in movements and maintenance of the posture, and furthermore enables attention to focus on the external world. Such being the premise, the "normal volition" described by Scheler implies precisely the transparency of the body that makes it an implicit background which allows to accomplish a simple goaloriented task without explicit effort on the movement. In other words, thanks to the body schema we experience a prevailing focus on the external world rather than on our body, which is why we can leave the room fluidly.

Some years later, in Der Formalismus in der Ethik und die materiale Wertethik, Scheler goes back to this problem and defines it by the clear phrase «das Schema unseres Leibes». ${ }^{9}$ The claim about this concept is even more radical: the unity of our body, which was already stressed in Die Idole, cannot arise from sensorial data like vision or touch plus some "organic sensations" (Organempfindungen). ${ }^{10}$ Hence, the phenomenologist asserts that the body schema is a structure that would exist even in the absence of any sensations, being rather the precondition for them. In other words, the proprioceptive unity does neither come from the body image in its visual and tactile aspects plus some sensations pertaining to the organs, nor from a physical body (Körper)+animation. The body as Leib can therefore come to evidence as «a completely unitary [einheitlicher] phenomenal state of affairs, and as the subject of «feeling» in such and such condition (So- und Anders«befindens»)». ${ }^{11}$ So when Scheler writes the "example of the newborn" in the Formalismus, this is what he has in his mind: the child comes to the world with an already-given unity of her lived body. How could she otherwise try to hit her feet, if she did not have a body-schematic dimension beforehand? What she learns to distinguish, is which optic image pertains to the bed sheets or to her body. It can be then desumed that, while according to Scheler the body schema

${ }^{7}$ GW III, pp. 242-3.

${ }^{8}$ GW III, p. 258.

${ }^{9}$ GW II, p. 409.

${ }^{10}$ GW II, p. 398.

${ }^{11}$ GW II, p. 399.

\begin{tabular}{|c|c|c|c|c|c|}
\hline intuitio & $\begin{array}{c}\text { ISSN } \\
1983-4012\end{array}$ & Porto Alegre & Vol.10- No.2 & $\begin{array}{c}\text { Dezembro } \\
2017\end{array}$ & p. 52-65 \\
\hline
\end{tabular}


does not need to be learnt, different is the phenomenology of the body image, which is instead not yet formed and connected to the schema.

It is important to mention one last text of Scheler's that concerns corporeality. In 1928, before his death, he gave a conference paper to the publishing house Otto Reichl in Darmstadt - a text that was to be published with the title Die Stellung des Menschen im Kosmos. ${ }^{12}$ Here he develops an open and harsh anti-Cartesian criticism, against the dualistic conception which forgot the unity of life in living beings (of which the psychical and the lived-body dimensions are two aspects), and the impulsive structure (Triebstruktur) that is distinctive of every animal, mankind included. Scheler refers to an elementary level of individuation that pertains to the animal Leibschema and its contents, linked to the "retroaction" or "feedback" (Rückmeldung). This means that the animal is given to itself a second time, or in other words individuated, thanks to the separation between sensorial and motor systems, and to the consciousness that it has of its body schemata and sensible contents. ${ }^{13}$ Consciousness does not imply the explicit selfconsciousness that only mankind owns and that allows it to objectify the psychic processes themselves. However, although the animal has a non-reflective kind of consciousness that differentiates it from a merely-animated plant, it lives still immersed in the environment, so only at a primary level of individuation. ${ }^{14}$ But this - it should be highlighted - occurs thanks to the body schema.

However, some questions might be asked about the difference between non-human animals and mankind: first of all, does the animal have a body image? Scheler would deny at least the conceptual aspect of it, since the animal is ecstatically immersed in its environment, and this means that it cannot properly have objects, therefore it cannot objectify its body. ${ }^{15}$ But is the difference between a cub and a child more basic, namely, does it concern the body schema? Guido Cusinato rightly points out that, contrarily to an animal, a human being goes through a never-ending birth. ${ }^{16}$ While, for instance, a dolphin is born with a quite well-developed body schema (that is, it can swim immediately after birth), a newborn is in this sense poorly equipped. In fact, she cannot walk nor survive without being taken care of, and her body schema itself is in continuous development to reach its full complexity (coordination of movements, capacity to sit upright, to stand straight, to walk, and so on). My investigation will concern two interconnected facets of the discussed body schema in Scheler, together with the examination of some infant studies:

\footnotetext{
${ }^{12}$ GW IX.

${ }^{13}$ GW IX, p. 41.

${ }^{14}$ GW IX, 34 ff.

15 This Schelerian claim would deserve further discussion, since some animals actually seem able to recognize their visual body image in the mirror: cf. PARKER, S.T., MITCHELL, R., BOCCIA, M.L., Self-awareness in animals and humans, Cambridge: Cambridge University Press, 1994.

${ }^{16}$ CUSINATO, G., Sharing emotions come fondamento motivazionale delle relazioni di cura (forthcoming).
}

\begin{tabular}{|c|c|c|c|c|c|}
\hline intuitio & $\begin{array}{c}\text { ISSN } \\
1983-4012\end{array}$ & Porto Alegre & Vol.10-N N .2 & $\begin{array}{c}\text { Dezembro } \\
2017\end{array}$ & p. 52-65 \\
\hline
\end{tabular}


Bodily individuation, bodily relationality - Scheler's phenomenology of the body and infant research

1) a child seems to have already a body schema at birth, since she is able to imitate facial gestures, which would not be possible without an implicit knowledge of her body; this proves that the human being enters the world with a certain self-individuation, if we share Scheler's theory in Die Stellung. But what are the precise levels of self-awareness and self-individuation of an infant?

2) Leib and Körper are two different aspects of the same body, of which only the lived dimension is primarily given. The Leibschema, however, is not complete at birth: does it need interactions in order to achieve full development? And how is it possible, given the studies on the matter that I am going to examine, that children seem to perceive some expressions as meaningful from early infancy? Do they show a tendency to exchange emotions and intentions bodily? As Scheler states in Wesen und Formen der Sympathie, the lived body is first of all a field of expressions, so what is given to perception in the first place are emotions and intentions.

\section{Is the infant self-individuated?}

According to Scheler's theory of the body schema, this bodily aspect is a pre-noetic unity in consciousness, a structure that allows all animals sensations and movements, and a primary individuation. Why then would it be controversial to claim that a child is born with this kind of individuation? A reason for misunderstanding might be the theory of the undifferentiated flux (undifferenzierte Strom) in Wesen und Formen der Sympathie, which claims that the I-thou difference emerges from a state of undifferentiation and that one lives more in the others than in oneself. Scheler also states that the child slowly raises her "mental" head (sein eigenes geistiges Haupt) above the stream, and «finds herself as a being who also, at times, has feelings, ideas and tendencies of his own». ${ }^{17}$ But which kind of self are we here dealing with? Does Scheler deny any self-individuation in early infancy?

Merleau-Ponty criticizes Scheler for reducing the problem of consciousness to a sort of panpsychism, in which «there is no individuation of consciousness». ${ }^{18}$ How could a non-self-conscious subject - he wonders - ever emerge from that undifferentiated flux? However, a more complex view of individuation comes clearly from the examination of Scheler's concepts of the body and the body schema. Given his division between sensible, vital, psychic values and values of the "holiness" (explained mainly in the Formalismusbuch), that correspond to various aspects of any human being on top of which is the personality, it is apparent that the body schema cannot be at the level either of the spiritual values or the psychic ones. A lived body is not even a mere sum of sensations, as it has been shown, and it is something that pertains to the animal world. So when Scheler speaks of a "mental head", he refers to the third level

\footnotetext{
${ }^{17}$ GW VII, p. 241.

${ }^{18}$ MERLEAU-PONTY, M., Merleau-Ponty à la Sorbonne: resumé de cours 1949-1952, Grenoble: Cynara, 1988, p. 44 (my translation).
}

\begin{tabular}{|c|c|c|c|c|c|}
\hline intuitio & $\begin{array}{c}\text { ISSN } \\
1983-4012\end{array}$ & Porto Alegre & Vol.10- $\mathrm{N}^{\circ} .2$ & $\begin{array}{c}\text { Dezembro } \\
2017\end{array}$ & p. 52-65 \\
\hline
\end{tabular}


of values, which in other terms would be applied to the quoted sentence as an "explicit selfconsciousness": the formation of an autonomous psychic self, that distinguishes itself from the contagion of tradition and of the people around her, comes with a more complex kind of individuation. But, if he attributes individuation and (pre-reflective) consciousness to the animal world, it would make no sense to claim that his notion of undifferentiated flux affects the lived-bodily level too. Animals have a bodily consciousness, even though a psychic level of values is not mentioned by Scheler when writing about them. Moreover, going back to the example of the newborn, Scheler denies a body image to the child, but the fact of hitting her feet would not be possible for the child in the absence of a body schema.

In 1977, Meltzoff and Moore started a series of experiment that tested the capacity of gesture imitation, like tongue protrusion and mouth opening, in infants since the first days of birth. The two authors interpret their results in favour of «the neonate's capacity to represent visually and proprioceptively perceived information in a form common to both modalities». ${ }^{19}$ Another way to read the well-known experiments by Meltzoff and Moore could be to individuate empirical evidence of the presence of a body schema from birth. How could a newborn otherwise imitate any gesture, if she could neither have any insight of the localization of her mouth, nor any pre-reflective knowledge of the embodied possibilities to perform those movements?

According to Rochat, there are 5 levels of self-awareness that the infant develops within the first years of life. He argues that a neonate is not born with a level 0 , that is a level of confusion or zero degree of self-awareness. Although Rochat refers to the child's self-perception in the mirror, he states something interesting that goes towards a primary individuation through the body schema:

It appears that immediately after birth, infants are capable of demonstrating already a sense of their own body as a differentiated entity: an entity among other entities in the environment (level 1). This is evident, for example, when observing the rooting response of newborns and what triggers it. When touching the cheek of newborns, they tend to orient their head toward the touch stimulation. (...) From birth, infants differentiate between self- vs. non-self touch, between stimulation originating from either the own body or an external source ${ }^{20}$.

In other words, neonates show a self-individuation that relies on the implicit differentiation between a quality of first-person and the external world. This occurs through the body schema, since the first-personal quality of bodily experiences shows in the first place a bodily I-thou differentiation (see the originary unity that pertains to the body schema according to Scheler). Even Scheler would not deny this claim, if the "I-thou" is not intended on the psychological, explicit level. Self-awareness remains implicit until the middle of the second year, according to Rochat: it is expressed in perception and action.

\footnotetext{
${ }^{19}$ MELTZOFF, A.N., MOORE, M.K., "Imitation of Facial and Manual Gestures by Human Neonates". In: Science, vol. 198, no. 4312, 1977, p. 78.

${ }^{20}$ ROCHAT, P., "First levels of self-awareness as they unfold in early life". In: Consciousness and Cognition, no. 12, 2003, p. 722.
}

\begin{tabular}{|c|c|c|c|c|c|}
\hline intuitio & $\begin{array}{c}\text { ISSN } \\
1983-4012\end{array}$ & Porto Alegre & Vol.10- $\mathrm{N}^{\circ} .2$ & $\begin{array}{c}\text { Dezembro } \\
2017\end{array}$ & p. 52-65 \\
\hline
\end{tabular}


In a similar way, Fogel highlights the early presence of an embodied self-awareness (ESA). This concept is composed by interoception and body schema, this last being the part of ESA that includes the sense of ownership, sense of movement and balance, the location of bodily parts, the sense of our bodily shape, and the awareness of the boundaries that divide us from the rest of the world. ${ }^{21}$ What the abovementioned authors have in common is to attribute the newborn both proprioception and a sense of self-world differentiation. To use Scheler's words: «[b]ut the difference between the spheres of "lived body" and "external world" is taken for granted since a long time; she [the child] does not "learn" to distinguish the two spheres themselves, but rather which visual things (Sehdinge) pertain to the one or to the other». ${ }^{22}$ After such Schelerian analysis, it can be claimed that a body image in infancy might be not formed - or not completely formed yet - as Talia Welsh supports; nevertheless, unlike Welsh's restrictive concept of self-awareness as an explicit and cognitive achievement, there is evidence for a minimal, embodied selfindividuation which relies on the implicit body-schematic dimension ${ }^{23}$.

\section{A relational body?}

It has been claimed so far that the child is born with an already given body schema, but does this mean that she is also self-sufficient, and that the body schema itself does not undergo fundamental changes thanks to the interrelational dimension? The corporeal conditions of a newborn seem to prove the contrary. Referring to this problem, the notion of human neoteny has been debated since Bolk's Das Problem der Menschwerdung, and is right in stressing that the human animal has the peculiarity of being born with an insufficiently developed cerebral and bodily structure. A child is born with an underdeveloped cortical region, which surely has a great plasticity or capacity to store information and learn, but also needs external stimuli from others and the world. ${ }^{24}$ Thanks to others' care, time and

\footnotetext{
${ }^{21}$ FOGEL, A., "Embodied Awareness: Neither Implicit nor Explicit, and Not Necessarily Nonverbal". In: Child Development Perspectives, vol. 5, no. 3, 2011, p. 184.

${ }^{22}$ GW II, p. 402.

${ }^{23}$ Welsh develops a critique to the experiments by Meltzoff and Moore arguing that they cannot be interpreted as evidence for newborn imitation; however, to do that she appeals to an explicit theory of mind, claiming about selfawareness that «[s]ome ability to recognize my own subjective experience as my subjective experience would lay the foundation for distinguishing self-awareness from awareness. (...) I don't think my cats understand that my feeding or not feeding them is based on my own internal decision-making process» (WELSH, T., "Do Neonates Display Innate Self-Awareness? Why Neonatal Imitation Fails to Provide Sufficient Grounds for Innate Self- and OtherAwareness", In: Philosophical Psychology, vol. 19, no. 2, 2006, p. 222). If we assume the primacy of an embodied individuation, however, there is no need for cognitive processes to explain the self-other differentiation.

${ }^{24}$ Cf. TREVARTHEN, C., "What Is It Like to Be a Person Who Knows Nothing? Defining the Active Intersubjective Mind of a Newborn Human Being". In: Infant and Child Development, no. 20, 2011, pp. 119-135.
}

\begin{tabular}{|c|c|c|c|c|c|}
\hline intuitio & $\begin{array}{c}\text { ISSN } \\
1983-4012\end{array}$ & Porto Alegre & Vol.10 - N .2 & $\begin{array}{c}\text { Dezembro } \\
2017\end{array}$ & p. 52-65 \\
\hline
\end{tabular}


interaction she will learn bodily, emotional and cognitive skills, such as walking or sharing emotional responses to a situation. ${ }^{25}$

Moreover, it is interesting to notice that infants seem to be predisposed to what Scheler calls expressivity (Ausdruck). More precisely, to state that the Leib (and not the Körper) is originarily given is not only true for self-awareness, but also for the perception of others, and the lived body is, according to Scheler, primarily a field of expressions. ${ }^{26}$ If someone, for instance, opens up in a smile with half-closed corners of her eyes, and comes with outstretched arms protruded towards us, we will not need an inferential thought to understand her intention of a hug and the cheerful mood in which she is. It is no surprise then, if the theory of expressivity is held true, that a newborn just few days old is already capable of imitating certain facial gestures, since she probably perceives them as meaningful much sooner than other gestures that need time to be learnt. Moreover, if the Leib and expression are primarily given in perception, it follows that animation too is a primary fact. Learning is instead a de-animation (Entseelung), not an animation (Beseelung) of a körperlich dimension. ${ }^{27}$

The primacy of expressivity seems to be confirmed by infant studies, since neonates manifest sensitivity to their partners' expressions and a tendency to communicate emotions and intentions bodily. The studies by Meltzoff and Moore examined show not only that newborns own a body schema and are able to imitate expressions thanks to it, but also that they are prone to enter a number of interactive situations from the beginning of their lives. Meltzoff himself interprets the results of his experiments as the presence of a primary sense of self, which increasingly develops from proprioceptive awareness. This, combined with the affective tone felt in the imitative effort, plus the social mirroring experienced with the caregiver, strengthens the infant's sense of agency. According to him, the child possesses a "body scheme" from birth, and this is extended and improved by social experiences and self-practice. ${ }^{28}$ Besides, it has been proved that the correct cognitive maturation of a child finds its basis in a coherent exchange of expressions and emotions. The post-natal depressed mothers, for instance, show insensitivity, hostility or poor expressive response to the child, and this impairs the infant's normal emotional regulation and cognitive development. ${ }^{29}$

\footnotetext{
${ }^{25}$ On the advantages for the development of culture and social life thanks to the neotenic condition cf. CUSINATO, G., "L'eccedenza espressiva: Creatività umana e inaugurazione della singolarità". In PAGLIACCI, D., Creatività ed eccedenza dell'umano, Roma: Aracne, 2015, pp. 15-32.

${ }^{26}$ I discuss this Schelerian concept more extensively in BRUTTOMESSO, M.C., "Empathy, expressivity, perception. A Phenomenological Analysis from a Schelerian Perspective". In: Rivista Internazionale di Filosofia e Psicologia, vol. 7, no. 3, 2016, pp. 350-364.

${ }^{27}$ GW VII, p. 233.

${ }^{28}$ MELTZOFF, A.N., "Foundations for Developing a Concept of Self: The Role of Imitation in Relating Self to Other and the Value of Social Mirroring, Social Modeling, and Self Practice in Infancy". In: CICCHETTI, D., BEEGHLY, M., The Self in Transition: Infancy to Childhood, Chicago: University of Chicago Press, 1990, pp. 139164.

${ }^{29}$ Cf. MURRAY, L., COOPER, P., FEARON, P., "Parenting Difficulties and Postnatal Depression: Implications for
}

\begin{tabular}{|c|c|l|l|c|c|}
\hline intuitio & $\begin{array}{c}\text { ISSN } \\
1983-4012\end{array}$ & Porto Alegre & Vol.10- $\mathrm{N}^{\circ} .2$ & $\begin{array}{c}\text { Dezembro } \\
2017\end{array}$ & p. 52-65 \\
\hline
\end{tabular}


As Trevarthen claims, «[i]nfant human beings imitate other humans, not just to act like them, but to enter into a communicative and cooperative relationship with them by some transfer of the feeling of body action». ${ }^{30}$ More radically than Meltzoff, he appeals to the evidence that the organs connected with human communicative expression and sensitivity are developed during the early foetal stage, and that neurosciences show the early embryonic formation of the regions regulating eye movements, facial expressions and vocalizations. ${ }^{31}$ In an interesting way, Trevarthen also remarks that a proto-cultural interchange can be seen in newborns that draw an adult into synchronized negotiations of an arbitrary action, or in other words, a neonate is capable of an interactive, even teasing play with adults. Moreover, she shows to prefer interaction when certain human features are present (sounds, odours, cadences of movements, and so on). ${ }^{32}$ This proves the infant's early ability of adapting her behaviour to others, which is already a sign of communicative intents. It is no surprise then that this author argues for an innate intersubjecitivity. ${ }^{33}$

The sensitivity to others' expressions and the communicative tendencies are shown even more clearly after the second-month transition. In this early transformation, face-to-face interaction and even the infant's active engagement increase, thanks to the improvement in the child's neural functions, to her motor development, and to the embodied change of her kind of contact with the caregiver (being less held often leads to major visual connection). ${ }^{34}$

Besides interaction, other relevant paradigms are the ones of co-regulation and attunement. Coregulation is a term used by Alan Fogel to describe the continuous adjustments that infant and caregiver perform in order to synchronise emotions and actions in communication, such as postural modifications and vocal and facial gestures. This is particularly visible after the second-month transition, and shows creativity and an active engagement in communication from both partners. ${ }^{35}$ In his turn, Daniel Stern has recently supported a "core intersubjectivity" which manifests itself from birth and shows the capacity to

Primary Healthcare Assessment and Intervention”. In: Community Practitioner, vol. 87, no. 11, 2014, pp. 34-38. This is a study carried out with infants between 6 weeks and 18 months, which shows the very early influence of interpersonal relations on development.

${ }^{30}$ TREVARTHEN, C., "What Is It Like to Be a Person Who Knows Nothing? Defining the Active Intersubjective Mind of a Newborn Human Being”. In: Infant and Child Development, no. 20, 2011, p. 124.

31 TREVARTHEN, C., "Foetal and neonatal psychology: Intrinsic motives and learning behaviour". In COCKBURN, F., Advances in perinatal medicine, New York/ Carnforth: Parthenon, 1997, pp. 282-291.

32 TREVARTHEN, C., "What Is It Like to Be a Person Who Knows Nothing? Defining the Active Intersubjective Mind of a Newborn Human Being”. In: Infant and Child Development, no. 20, 2011, p. 121.

33 TREVARTHEN, C., "Communication and cooperation in early infancy. A description of primary intersubjectivity". In: BULLOWA, M., Before speech: The beginning of human communication, London: Cambridge University Press, 1979, pp. 321-347.

${ }^{34}$ LAVELLI, M., FOGEL, A., "Developmental Changes in Mother-Infant Face-to-Face Communication: Birth to 3 Months". In: Developmental Psychology, vol. 38, no. 2, 2002, pp. 288-305.

${ }^{35}$ FOGEL, A., Developing Through Relationships: Origins of Communications, Self, and Culture, Chicago: University of Chicago Press, 1993.

\begin{tabular}{|c|c|l|l|c|c|}
\hline intuitio & $\begin{array}{c}\text { ISSN } \\
1983-4012\end{array}$ & Porto Alegre & Vol.10- $\mathrm{N}^{\circ} .2$ & $\begin{array}{c}\text { Dezembro } \\
2017\end{array}$ & p. 52-65 \\
\hline
\end{tabular}


take part in the others' experiences. ${ }^{36}$ This point further argues in favour of the claim of a body schema present from birth and already capable of interactions, but it is also worth examining his older theories that show a certain "Schelerian" structure. If it is true that infants in their first two months "will rapidly categorize the social world into conforming and contrasting patterns, events, sets, and experience», ${ }^{37}$ and that what they learn can never be completely split into "cognitive" and "affective" aspects, ${ }^{38}$ then it can be easily understood that in the following months the contact with the caregiver will become an effective form of "affective attunement". By this phrase, Stern defines a set of coherent mutual responses between infant and caregiver, in which an affect is coherently developed in interaction, a capacity that emerges around the ninth month. ${ }^{39}$ It is different from imitation, since what is kept is the affective tonality, but not the exact gestures, vocalizations, and so on, which implies that the affect is pre-noetically understood by both partners as correctly or non-correctly matching. I will not deal with the discussion on the "shared" feature here, since what I find particularly significant is the correspondence between Scheler's and Stern's theories about this concept.

First of all, what Stern claims to be attuned and matched is not the mere behaviour, but a feeling state, meaning that what appears to the partner is primarily expression. According to Scheler the lived body is primarily a field of expressions: the feeling or emotion is perceived as a first unitary thing (not as a sum of separate physical elements) and is present in the expression itself. ${ }^{40}$ In a similar way, Stern argues that «[w]e appear to be dealing with behavior as expression rather than as sign or symbol», ${ }^{41}$ that is, through a kind of direct Fremdwahrnehmung that can be related to the Schelerian approach. ${ }^{42}$ In fact, attunement occurs almost completely out of (explicit) awareness, and quasi-automatically. ${ }^{43}$ Furthermore, there is a striking correspondence with Scheler's (lived-) bodily and vital feelings (Leibgefühle and Lebensgefühle), which are kinds of feeling states (Gefühlzustände) that allow the perception of corporeal values. ${ }^{44}$ Stern states in fact that most episodes of attunement seem to occur within the "vitality affects", which are defined as «those dynamic, kinetic qualities of feeling that distinguish animate from inanimate

36 STERN, M.D., “Intersubjectivity”. In: PERSON, E.S., COOPER, A.M., GABBARD, G.O., Textbook of Psychoanalysis, Washington/London: The American Psychiatric Publishing, 2005, pp.77-92.

37 STERN, M.D., The Interpersonal World of the Infant: A View from Psychoanalysis and Developmental Psychology, London: Karnac Books, 1985, p. 42.

38 STERN, M.D., The Interpersonal World of the Infant: A View from Psychoanalysis and Developmental Psychology, London: Karnac Books, 1985, p. 42.

39 STERN, M.D., The Interpersonal World of the Infant: A View from Psychoanalysis and Developmental Psychology, London: Karnac Books, 1985.

${ }^{40} \mathrm{GW}$ VII.

41 STERN, M.D., The Interpersonal World of the Infant: A View from Psychoanalysis and Developmental Psychology, London: Karnac Books, 1985, p. 142.

${ }^{42} \mathrm{GW}$ VII.

43 STERN, M.D., The Interpersonal World of the Infant: A View from Psychoanalysis and Developmental Psychology, London: Karnac Books, 1985, p. 145.

${ }^{44}$ Cf. GW II.

\begin{tabular}{|c|c|c|c|c|c|}
\hline intuitio & $\begin{array}{c}\text { ISSN } \\
1983-4012\end{array}$ & Porto Alegre & Vol.10- No.2 & $\begin{array}{c}\text { Dezembro } \\
2017\end{array}$ & p. 52-65 \\
\hline
\end{tabular}


and that correspond to the momentary changes in feeling states involved in the organic processes of being alive». ${ }^{45}$ Those vitality affects are experienced in a way that a gesture is not the mere sum of qualities like timing, intensity and shape (e.g., Stern says, rapid acceleration, speed, and fullness of display). A child will perceive the forcefulness of the gesture. ${ }^{46}$ Which indicates, again, the primacy of Ausdruck.

\section{Conclusion}

I have so far analysed empirical evidence both of the primary individuation, and of the intrinsically social component of the body schema, which by infant research is proved to manifest a tendency towards understanding expressivity in others. The question of the primacy of the individuation or the intrinsic relationality of the body has been examined through Scheler's theory of the Leib and some scientific evidence of early infant development. I have claimed that a basic form of individuation is present in Die Stellung and resolves some prima facie impasses that could be detected in Scheler's theory of the undifferentiated flux. As it has been shown, he did not deny the infant an implicit self-awareness that originates in the body schema, which is evident from other texts and especially from the "example of the newborn" in the Formalismus. A "corporeal" level of self-individuation, that according to Scheler allows the animal being to detach from the environment, is supported also by Rochat and Fogel, who assert the existence of a "level 1" of individuation and of an embodied self-awareness (ESA). Moreover, the well-known experiments by Meltzoff and Moore imply that the infant must possess already an implicit body schema from birth, in order to imitate gestures without having the image of their body yet.

On the other hand, the same experiments also demonstrate that the body schema is intrinsically relational, the baby being able to deal with basic gestures since the first hours after birth. I have shown that, despite this bodily self-individuation, the body schema of an infant is necessarily incomplete without interactions, and it is constituted in such a way that expressivity is the first feature that she catches in others. I have examined Scheler's notion of Ausdruck, which proves that the body schema is the ground for relationality too: what we perceive in others is a unity of expression, before splitting the single parts of a Körper. I have considered several insights in infant research as pertinent evidence, and suggest reconsideration of an innate intersubjectivity (Trevarthen) or core intersubjectivity (Stern). Even prelinguistic development indicates that the primary form of learning is through bodily communication, coregulation (Fogel) and affective attunement (Stern), which allows to share Scheler's theoretical claim on the direct perception of expressive phenomena. In the end, whether or not the body and body schema are

${ }^{45}$ STERN, M.D., The Interpersonal World of the Infant: A View from Psychoanalysis and Developmental Psychology, London: Karnac Books, 1985, p. 156.

46 STERN, M.D., The Interpersonal World of the Infant: A View from Psychoanalysis and Developmental Psychology, London: Karnac Books, 1985, p. 158.

\begin{tabular}{|c|c|l|l|c|c|}
\hline intuitio & $\begin{array}{c}\text { ISSN } \\
1983-4012\end{array}$ & Porto Alegre & Vol.10- $\mathrm{N}^{\circ} .2$ & $\begin{array}{c}\text { Dezembro } \\
2017\end{array}$ & p. 52-65 \\
\hline
\end{tabular}


Bodily individuation, bodily relationality - Scheler's phenomenology of the body and infant research

primarily individuated or relational is a catch-22 problem: interaction is possible from birth thanks to the body schema and therefore to a primary individuation, but at the same time bodily individuation is shown to be intrinsically open to alterity and developing through social contacts constantly.

\section{Acknowledgments}

I am grateful for the opportunity of receiving feedback on a preliminary version of such investigation at the conference of the Nordic Society for Phenomenology, 2017; I am also thankful to Guido Cusinato and Manuela Lavelli for their advice on the references and the insightful theoretical discussions.

\section{References}

BRUTTOMESSO, M.C., "Empathy, expressivity, perception. A Phenomenological Analysis from a Schelerian Perspective". In: Rivista Internazionale di Filosofia e Psicologia, vol. 7, no. 3, 2016, pp. 350-364.

CUSINATO, G., Katharsis: La morte dell'ego e il divino come aperture al mondo nella prospettiva di Max Scheler, Napoli: Edizioni Scientifiche Italiane, 1999.

CUSINATO, G., "L'eccedenza espressiva: Creatività umana e inaugurazione della singolarità". In PAGLIACCI, D., Creatività ed eccedenza dell'umano, Roma: Aracne, 2015, pp. 15-32.

CUSINATO, G., Sharing emotions come fondamento motivazionale delle relazioni di cura (forthcoming).

FOGEL, A., Developing Through Relationships: Origins of Communications, Self, and Culture, Chicago: University of Chicago Press, 1993.

FOGEL, A., "Embodied Awareness: Neither Implicit nor Explicit, and Not Necessarily Nonverbal". In: Child Development Perspectives, vol. 5, no. 3, 2011, pp. 183-186.

GALLAGHER, S., How the Body Shapes the Mind, Oxford: Clarendon Press, 2005.

LAVELLI, M., FOGEL, A., "Developmental Changes in Mother-Infant Face-to-Face Communication: Birth to 3 Months". In: Developmental Psychology, vol. 38, no. 2, 2002, pp. 288-305.

MELTZOFF, A.N., "Foundations for Developing a Concept of Self: The Role of Imitation in Relating Self to Other and the Value of Social Mirroring, Social Modeling, and Self Practice in Infancy". In: CICCHETTI, D., BEEGHLY, M., The Self in Transition: Infancy to Childhood, Chicago: University of Chicago Press, 1990, pp. 139-164.

MELTZOFF, A.N., MOORE, M.K., "Imitation of Facial and Manual Gestures by Human Neonates". In: Science, vol. 198 , no. 4312, 1977 , pp. 75-78.

MERLEAU-PONTY, M., Les Relations avec Autrui chez l'Enfant, Paris: Centre de Documentation Universitaire, 1951.

MERLEAU-PONTY, M., Merleau-Ponty à la Sorbonne: resumé de cours 1949-1952, Grenoble: Cynara, 1988.

MURRAY, L., COOPER, P., FEARON, P., "Parenting Difficulties and Postnatal Depression: Implications for Primary Healthcare Assessment and Intervention". In: Community Practitioner, vol. 87, no. 11, 2014, pp. 34-38.

PARKER, S.T., MITCHELL, R., BOCCIA, M.L., Self-awareness in animals and humans, Cambridge: Cambridge University Press, 1994.

ROCHAT, P., "First levels of self-awareness as they unfold in early life". In: Consciousness and Cognition, no. 12, 2003, pp. 717-731.

SCHELER, M., Gesammelte Werke, II: Der Formalismus in der Ethik und die materiale Wertethik (1913/16; 1927), Bonn: Bouvier-Verlag, 2009.

SCHELER, M., "Die Idole der Selbsterkenntnis (Über Selbsttäuschungen, 1912)", In: Gesammelte Werke, III: Vom Umsturz der Werte. Abhandlungen und Aufsätze, Bonn: Bouvier-Verlag, 2007.

SCHELER, M., "Wesen und Formen der Sympathie". In: Gesammelte Werke, VII, Wesen und Formen der Sympathie - Die deutsche Philosophie der Gegenwart, Bonn: Bouvier-Verlag, 2005.

SCHELER, M., "Die Stellung des Menschen im Kosmos" (1928). In: Gesammelte Werke, IX: Späte Schriften, Bonn:

\begin{tabular}{|c|c|l|l|c|c|}
\hline intuitio & $\begin{array}{c}\text { ISSN } \\
1983-4012\end{array}$ & Porto Alegre & Vol.10- $\mathrm{N}^{\circ} .2$ & $\begin{array}{c}\text { Dezembro } \\
2017\end{array}$ & p. 52-65 \\
\hline
\end{tabular}


Bouvier-Verlag, 2008.

STERN, M.D., "Intersubjectivity". In: PERSON, E.S., COOPER, A.M., GABBARD, G.O., Textbook of Psychoanalysis, Washington/London: The American Psychiatric Publishing, 2005, pp.77-92.

STERN, M.D., The Interpersonal World of the Infant: A View from Psychoanalysis and Developmental Psychology, London: Karnac Books, 1985.

TREVARTHEN, C., "Communication and cooperation in early infancy. A description of primary intersubjectivity". In: BULLOWA, M., Before speech: The beginning of human communication, London: Cambridge University Press, 1979, pp. 321-347.

TREVARTHEN, C., "Foetal and neonatal psychology: Intrinsic motives and learning behaviour". In COCKBURN, F., Advances in perinatal medicine, New York/ Carnforth: Parthenon, 1997, pp. 282-291.

TREVARTHEN, C., "What Is It Like to Be a Person Who Knows Nothing? Defining the Active Intersubjective Mind of a Newborn Human Being”. In: Infant and Child Development, no. 20, 2011, pp. 119-135.

WELSH, T., "Do Neonates Display Innate Self-Awareness? Why Neonatal Imitation Fails to Provide Sufficient Grounds for Innate Self- and Other-Awareness", In: Philosophical Psychology, vol. 19, no. 2, 2006, pp. 221-238.

ZAHAVI, D., Self-awareness and Alterity, Evanston: Northwestern University Press, 1999.

Recebido em: 30/08/2017

Aprovado para a publicação em: 20/10/2017

\begin{tabular}{|c|c|c|c|c|c|}
\hline intuitio & $\begin{array}{c}\text { ISSN } \\
1983-4012\end{array}$ & Porto Alegre & Vol.10 - No.2 & $\begin{array}{c}\text { Dezembro } \\
2017\end{array}$ & p. 52-65 \\
\hline
\end{tabular}

